\title{
AKULTURASI ISLAM DAN BUDAYA LOKAL DALAM TRADISI “NYUMPET” DI DESA SEKURO KECAMATAN MLONGGO KABUPATEN JEPARA
}

\author{
Nurhuda Widiana \\ Sekolah Tinggi Agama Islam Negeri (STAIN) Pekalongan \\ Email:nh.widiana@gmail.com
}

\begin{abstract}
Abtract
Acculturation is a concept to describe the long process of confergence of two or more values which are owned by individual, group and society. The emergence of regention to new value system, must be understood as a part of love the society against old values (local). This is a process of learning to understand the new values is coming. In theses condition, isn't appropriate to use claims of winning or losing, between Islam vis a vis the local culture. The view of Islam in society, will be strongly colored by its culture. So that, Islam will be have variant which suitable various with the heteroginas culture that exists in the society. This condition is being constantly will be occurring of up - down, whether Islam will be more colouring culture or otherwise the culture will be colouring of Islam. The tradition of "Nyumpet" in Sekuro village, into one small of example to explain the process of acculturation is running. In this where the preacher must be more prudently in the dealing with religious practice which banded in a local culture that still rooted in the society.

Akulturasi merupakan konsep untuk menggambarkan proses panjang bertemunya dua atau lebih tata nilai yang dimiliki individu, kelompok dan masyaraka. Munculnya penolakan terhadap tata nilai baru, harus dipahami sebagai bagian kecintaan masyarakat terhadap nilai-nilai lama (lokal). Hal ini merupakan proses belajar untuk memahami nilai-nilai baru yang datang. Pada kondisi seperti ini, tidak tepat digunakan klaim menang atau kalah, antara Islam vis a vis budaya lokal. Tampilan Islam di suatu masyarakat, akan sangat diwarnai oleh budaya yang dimilikinya. Sehingga Islam akan memiliki varian yang bermavam-macam sesuai dengan heteroginas budaya yang eksis di masyarakat. Kondisi ini secara terus-menerus akan mengalami pasang-surut, apakah Islam akan lebih mewarnai budaya atau sebaliknya budaya akan mewarnai Islam. Tradisi "Nyumpe"t di desa Sekuro, menjadi salah satu contoh kecil untuk menjelaskan proses akulturasi yang berjalan.Disinilah para da'I harus lebih bijaksana dalam menyikapi praktik keagamaan yang terbalut dalam budaya lokal yang masih mengakar di masyarakat.
\end{abstract}

Keywords: Islam, local culture, "nyumpet". 


\section{A. Pendahuluan}

A.L. Kroeber dan Clyde Kluckhon dalam bukunya Cultural: A Critical Review of Concepts and Devinitions, telah mengumpulkan kurang lebih 161 definisi tentang kebudayaan. Dalam garis besarnya definisi-definisi tersebut kemudian ditinjau dari berbagai sudut pandang. Salah satu definisi tersebut, kebudayaan dapat ditinjau dari pendekatan genetik yang memandang kebudayaan sebagai suatu produk, alat-alat, benda-benda atau suatu simbol. ${ }^{1}$ Sementara ahli antropologi Leslie White ${ }^{2}$ berpendapat bahwa semua prilaku manusia dimulai dengan penggunaan lambang. Seni, agama, dan uang melibatkan penggunaan lambang. Kita semua mengetahui semangat dan ketaatan yang dapat dibangkitkan oleh agama pada orang yang percaya. Sebuah salib atau sebuah gambar misalnya dapat mengingatkan kepada perjuangan dan penganiayaan yang berabad-abad lamanya atau dapat menjadi pengganti sebuah filsafat atau kepercayaan yang lengkap pada orang Kristen. Atau sebuah gambar Ka'bah dapat memotivasi seseorang untuk menyempurnakan ibadah dan rukun Islam.

Berkaitan dengan budaya Islam sebagai sistem ajaran agama akan selalu berdialog dengan budaya lokal dimana Islam berada. Meski akhirnya terdapat salah satu yang berpengaruh baik agama atau justru sebaliknya budaya lokal yang lebih dominan dalam kehidupan manusia. Namun besar kemungkinan keduanya dapat memainkan peran penting dalam membentuk budaya baru, karena terjadi dialog antara tatanan nilai agama yang menjadi idealisme suatu agama dengan tata nilai budaya lokal.

Antara kebudayaan dan agama, Geertz ${ }^{3}$ memahami agama sebagai sistem kebudayaan. Dalam pandangannya kebudayaan sebagai pola

${ }^{1}$ Lihat A.L Krober dan Clyde Kluckhonhn, Cultural: Critical Review of Concept and Devinitions, (Massachussel: The Museum, 1952), dalam Musa Asy'ari, Manusia Pembentuk Kebudayaan dalam al-Qur'an, (Yogyakarta: LESFI, 1992), hlm. 93

${ }^{2}$ Leslie White (1900-1975) adalah seorang teoritikus besar dibidang antropologi Amerika Utara, yang melihat kebudayaan sebagai kumpulan dari ketiga komponen, yakni komponen tekno-ekonomis, komponen social, dan komponen ideology. Lihat di William A. Haviland, Antropologi Edisi 1,(Jakarta: Erlangga, 1985) , hlm.339.

3 Geertz memiliki nama lengkap Clifford Geertz, lahir di San Francisco, pada tanggal 23 Agustus 1926, di Amerika Serikat. Ia adalah seorang antropolog yang sering melakukan kajian di Indonesia, yang berhubungan dengan agama dan masyarakat, dan kemudian memperkenalkan antropologi Indonesia ke dunia luar. Kajian dan penelitiannya dalam bidang antropologi tertuang dalam karyanya "The Religion of Java" yang telah diterjemahkan dalam bahasa Indonesia "Abangan, Santri dan Priyayi dalam masyarakat Jawa". Ia juga dikenal sebagai antropolog yang mengembangkan paradigma simbolikinterpretatif yang banyak menemukan tempat di Indonesia karena pluralitas bangsa 
kelakuan yang terdiri dari serangkaian aturan-aturan, pedoman-pedoman, petunjuk-petunjuk yang digunakan manusia untuk mengatur tingkah lakunya. Dengan demikian kebudayaan dapat diartikan dari pengorganisasian pengertian-pengertian yang tersimpul dalam simbol-simbol yang berkaitan dengan ekspresi manusia. Karena itu Geertz kemudian memahami agama tidak saja sebagai seperangkat nilai di luar manusia tetapi juga merupakan sistem pengetahuan dan sistem simbol yang memungkinkan terjadinya pemaknaan.

Itulah sebabnya secara historis Islam datang ke berbagai belahan nusantara dengan suasana yang relatif damai nyaris tanpa ketegangan dan konflik. Islam dengan mudah dapat diterima oleh masyarakat sebagai sebuah agama yang membawa kedamaian, meskipun pada masa itu masyarakat telah beragama dan memiliki kepercayaan tersendiri baik animisme, dinamisme, hindu maupun budha. Penyebaran Islam menyebabkan munculnya corak dan varian Islam yang memiliki kekhasan dan keunikan. Hal ini harus disadari bahwa eksistensi Islam di Indonesia tidak pernah tunggal.

Dalam mempercepat perkembangan masyarakat, kita tidak pernah mengesampingkan kiprah Walisongo. ${ }^{4}$ mereka selalu menghargai tradisi dan budaya asli dalam menyebarkan agama Islam. Metode mereka sesuai dengan ajaran Islam yang lebih toleran dengan budaya lokal. Hal ini juga merupakan kemasyhuran cara-cara persuasif yang dikembangkan Walisongo dalam mengislamkan Pulau Jawa atas kekuatan Hindu-Budha pada abad 15 dan $16 \mathrm{M}$. Apa yang terjadi adalah bukan suatu intervensi, tetapi lebih pada akulturasi dan hidup berdampingan secara damai. Ini merupakan suatu ekspresi dari "budaya Islam " yaitu ulama sebagai agen of change, dipahami secara luas telah memelihara dan menghargai tradisi lokal dengan cara subordinasi budaya tersebut terhadap nilai-nilai Islam.

Dalam makalah ini penulis lebih spesifik mengkaji tentang pergumulan Islam dan budaya lokal Jawa yang bersinggungan dengan proses akulturasi dan asimilasi, serta apa makna Islam sebagai sistem simbol? Untuk memperdalam kajian ini, penulis akan mengangkat studi kasus masyarakat Samin di dusun Jepang Bojonegoro Jawa Timur.

Indonesia. Baca: Nur Syam, Madzhab-madzab Antropologi, (Yogyakarta: LKIS, 2007), hlm.1113.

${ }^{4}$ Walisongo biasanya dihubungkan dengan sufisme jawa masa-masa awal. Wali lebih kurang diartikan sebagai "orang suci", sedangkan songo dalam bahasa jawa berarti Sembilan. Walisongo berarti Sembilan orang suci yang diyakini telah mengislamkan jawa pada abad ke-15 dan 16 M. Baca Anasom (ed), "Merumuskan kembali Interelasi Islam-Jawa", (Yogyakarta: Gama Media bekerjasama dengan Pusat Kajian Islam dan Budaya Jawa IAIN Walisongo Semarang, 2004), hlm.xiv. 


\section{B. Islam Sebagai Sistem Simbol}

Kehidupan manusia penuh diwarnai dengan simbol-simbol. Dalam sejarah manusia, ditemukan tindakan-tindakan manusia yang berhubungan dengan agama, politik, ekonomi dan lain sebagainya didasarkan pada simbol-simbol. Menurut Ernest Cassirer ${ }^{5}$ manusia tidak pernah melihat, menemukan, dan mengenal dunia secara langsung kecuali melalui simbol. Kenyataan memang sekedar fakta-fakta, meski fakta tetapi memiliki makna psikis juga, karena simbol mempunyai unsur pembebasan dan perluasan pandangan. Begitu eratnya kehidupan manusia dengan simbol-simbol, sampai manusia disebut makhluk dengan simbol-simbol (homo simbolicus). Manusia berpikir, bertindak, bersikap, berperasaan dengan ungkapan-ungkapan yang simbolis.

Manusia mengalami tiga tingkatan dalam kehidupannya yaitu statis, dinamis dan religious. Setelah melalui tingkatan ini manusia akan mendekatkan diri pada Tuhan. Manusia yang beragama dengan baik akan selalu menjauhi larangannya, dan melaksanakan perintah-perintah Tuhannya. Dengan ungkapan lain dapat dikatakan bahwa beragama berarti menyerahkan diri kepada Tuhan. Penyerahan diri kepada Tuhan dilakukan dengan simbol-simbol.

Menurut Elizabeth K. Nothingham ${ }^{6}$, inti emosi keagamaan tidak dapat diekspresikan, hanya dapat diperkirakan karena itu hanya bisa bersifat simbolik. Meski demikian untuk dapat memberi makna tentang sesuatu yang ghaib dan sakral pada pemeluk agamanya maka dipakai simbolisme, meski kurang tepat dibandingkan dengan cara-cara ekspresi yang lebih ilmiah tetapi mempunyai potensi istimewa. Menurutnya simbol mampu membangkitkan perasaan dan keterkaitan lebih dari sekedar formulasi verbal dari benda-benda yang mereka percayai sebagai simbol tersebut. Simbol-simbol tersebut merupakan pendorong-pendorong yang paling kuat bagi timbulnya perasaan manusia.

Koentjaraningrat ${ }^{7}$ menyebutkan ada empat komponen dalam sistem agama. Pertama, emosi keagamaan menyebabkan manusia bersifat religious. Emosi keagamaan merupakan suatu getaran yang menggerakkan jiwa manusia. Proses ini terjadi apabila jiwa manusia memperoleh cahaya

\footnotetext{
${ }^{5}$ Cassirer, E. , An Essay on Man, An Introduction to Philosophy of Human Culture, (New York: New Heaven, 1994), hlm. 23.

${ }^{6}$ Elizabeth K.Nothingham, Elizabeth K, Agama dan masyarakat, (Jakarta: Rajawali Press, 1997), hlm. . 16-17.

7 Koentjaraningrat, Kebudayaan, Mentalitet, dan Pembangunan,( Jakarta: Gramedia, 1974), hlm. 17
} 
dari Tuhan. Getaran jiwa yang disebut emosi keagamaam tadi dapat dirasakan seorang individu dalam keadaan sendiri. Suatu aktifitas keagamaan dapat dilakukan dalam keadan sunyi senyap. Seseorang bisa berdoa bersujud,atau melakukan sembahyang sendiri dengan penuh hidmat. Manakala dihinggapi emosi keagamaan, ia akan membayangkan Tuhannya. Kedua, sistem kepercayaan yang mengandung keyakinan serta imajinasi manusia tentang Tuhan, keberadaan alam gaib, dan makhlukmakhluk gaib dan lain sebagainya. Keyakinan-keyakinan seperti itu biasanya diajarkan pada manusia dari kitab suci yang bersangkutan. Sistem kepercayaan erat hubungannya dengan sistem ritual keagamaan dan menentukan tata urut dan unsur-unsur acara, serta dan prasarana yang digunakan dalam unsur keagamaan. Ketiga, sistem ritual keagamaan yang bertujuan mencari hubungan manusia dengan Tuhan. Sistem keagamaan ini melambangkan konsep-konsep yang terkandung dalam sistem kepercayaan. Keempat, kelompok-kelompok keagamaan bisa berupa organisasi sosial keagamaan, organisasi dakwah atau penyiaran keagamaan yang juga menggunakan simbol-simbol dengan ciri khas keagamaan masing-masing kelompok keagamaan tersebut.

Sebagai sistem pengetahuan, agama merupakan sistem keyakinan yang sarat ajaran moral dan petunjuk kehidupan yang harus dipelajari, ditelaah kemudian dipraktekkan oleh manusia dalam kehidupannya. Dalam hal ini agama memberikan petunjuk mengenai yang "baik dan buruk yang pantas dan tidak pantas" dan yang "tepat dan tidak tepat". Nilai-nilai agama dapat membentuk dan membangun perilaku manusia dalam kesehariannya.

Islam sebagai sistem simbol, memiliki simbol-simbol tertentu untuk mengaktualisasikan ajaran agama Islam. Baik simbol yang dimaksud berupa perbuatan, kata-kata, benda, sastra, dan sebagainya. Sujud misalnya bentuk simbolisasi atas kepasrahan dan penghambaan penganutnya pada pencipta. Sujud merupakan simbol totalitas kepasrahan hamba dan pengakuan secara sadar akan kemaha besaran Allah. Dalam hal ini sujud yang terdapat dalam sholat merupakan bagian dari ritual keagamaan dalam kehidupan masyarakat beragama. ${ }^{8}$. Karena itu tidak sukar dipahami

${ }^{8}$ Ritual keagamaan merupakan bagian dari praktek keagamaan (religious practice) yang dilakukan penganutnya dalam rangka pengabdian, menyembah atau menghormati Tuhan yang diimaninya. Selain praktek keagamaan, dimensi agama dipandang secara sosiologis dapat diklasifikasikan sebagai system keyakinan (religious belief) dan dimensi pengalaman beragama (religious ekspeience dimension). Dimensi pertama berkaitan dengan pengakuan dan penerimaan terhadap sesuatu atau dzat "yang sacral", "Y ang Maha Besar" sebagai suatu kebenaran atau suatu kenyataan. Sementara dimensi pengalaman beragama meliputi perasaan dan persepsi tentang proses kontaknya dengan apa yang diyakini sebagai 
bahwa dimilikinya simbol bersama merupakan cara yang paling efektif untuk mempererat persatuan diantara para pemeluk agama. Ini karena makna simbo-simbol tersebut menyimpang jauh dari definisi-definisi intelektual sehingga kemampuan simbol-simbol tersebut untuk mempersatukan lebih besar, sedangkan definisi intelektual menimbulkan perpecahan. Simbol-simbol bisa dimiliki bersama karena didasari perasaan yang tidak dirumuskan terlalu ketat.

\section{Islam dan Budaya Lokal: Keniscayaan Dialog}

Menurut Denys Lombard kaum muslimin sebagai suatu kebulatan adalah sesuatu yang mustahil. ${ }^{9}$ Islam di Indonesia memang tampak berbeda dengan Islam di berbagai belahan dunia lain, terutama dengan tata cara yang dilakukan di jazirah Arab. Persentuhan antara tiga hubungan kepercayaan pra Islam (animisme, Hindu dan Budha) tetap hidup mewarnai Islam dalam pengajaran dan aktifitas ritual pemeluknya. Karena itu menurut Martin Van Bruinessen ${ }^{10}$, Islam khususnya di Jawa, sebenarnya tidak lebih dari lapisan tipis yang secara esensial berbeda dengan transendentalisme orientasi hukum Islam di wilayah Timur Tengah. Hal ini disebabkan kerena praktek keagamaan orang-orang Indonesia banyak dipengaruhi oleh agama India (Hindu dan Budha) yang telah lama hidup di kepulauan Nusantara, bahkan lebih dari itu dipengaruhi agama-agama penduduk asli yang memuja nenek moyang dan dewa-dewa serta roh-roh halus.

Hal ini dapat dipahami karena setiap agama tak terkecuali Islam, tidak lepas dari realitas dimana ia berada. Islam bukanlah agama yang lahir dalam ruang yang hampa budaya. Antara Islam dan realitas, meniscayakan adanya dialog yang terus berlangsug secara dinamis ${ }^{11}$.Ketika Islam

sang ilahi serta penghayatan terhadap hal-hal yang bersifat religious, misalnya perasaan senang mendengar bacaan al-Qur'an, shalawat, adzan. Perasaan tersebut merupakan bagian dari pengalaman beragama yang hanya dapat dirasakan oleh orang-orang tertentu yang memiliki penghayatan tinggi terhadap ajaran agama. M. Ali al-Humaidy, "Tradisi Molodhan: Pemaknaan Kontekstual Ritual Agama Masyarakat pamekasan Madura, dalam Jurnal ISTIQRA', Jurnal penelitian Islam Indonesia, Volume 06, Nomor 01 2007, hlm.282-284.

${ }^{9}$ Lombard, Denys, Nusa Jawa Silang Budaya, terjemahan, (Jakarta: Gramedia, 1996), hlm. 86.

10 Bruinessen, Martin Van, "Global and Local in Indonesia Islam" dalam Southeast Asian Studies, Kyoto: vol 37, No 2, 1999, hlm. 46-63.

11 Bahkan jika ditelusur lebih jauh, Islam pun merupakan produk lokal yang diuniversalkan dan ditrandensi. Dalam konteks Arab yang dimaksud dengan Islam sebagai produk lokal adalah Islam yang lahir di Arab, tepatnya di daerah Hijaz untuk menjawab 
menyebar ke Indonesia, Islam tidak dapat terlepas dari budaya lokal yang sudah ada dalam masyarakat. Antara keduanya meniscayakan adanya dialog yang kreatif dan dinamis, hingga akhirnya Islam dapat diterima sebagai agama baru tanpa harus menggusur budaya lokal yang sudah ada. Dalam hal ini budaya lokal yang berwujud dalam tradisi dan adat masyarakat setempat, tetap dapat dilakukan tanpa melukai ajaran Islam, sebaliknya Islam tetap dapat diajarkan tanpa mengganggu harmoni tradisi masyarakat.

Dialog kreatif antara budaya lokal tidaklah berarti "mengorbankan" Islam, dan menempatkan Islam kultural sebagai hasil dari dialog tersebut sebagai jenis Islam yang "rendahan " dan tidak bersesuaian dengan Islam yang "murni" --yang ada dan berkembang di jazirah Arab"12, tapi Islam kultural dapat dilihat sebagai bentuk varian Islam yang sudah berdialektika dengan realitas dimana Islam berada dan berkembang. Sebagai contoh agama Hindu yang ada di Bali. Hindu di Bali bukanlah sebagaimana Hindu yang ada di tempat kelahirannya India, tetapi merupakan hasil dari dialog kultural dan Hindu yang berkembang di Bali, Sehingga internalisasi agama terhadap pemeluknya lebih mudah dipahami dan ajaran-ajarannya dapat diaplikasikan sebagaimana ideal yang ada dalam agama tersebut.

Menjadi Islam tidak harus menjadi Arab. Islam memang lahir di Arab tetapi tidak hanya untuk masyarakat Arab. Arabisasi merupakan upaya politik berkedok purifikasi Islam yang berusaha menjadikan Islam menjadi satu dan seragam ${ }^{13}$. Dalam pemahaman mereka, Islam kaffah adalah Islam

persoalan-persoalan yang ada dan berkembang saat itu. Islam Arab itu berkembang ketika bertemu dengan kebudayaan lain, termasuk Indonesia. Maka dalam hal ini Islam senantiasa mengalami dinamisasi kebudayaan dan peradaban. Baca, "Pergumulan Hukum Islam dan Budaya Sasak; Mengarifi Fiqh Islam Wetu Telu” dalam Jurnal ISTIQRO', Jurnal Penelitian Islam Indonesia, Volume 06, No 1, 2007. hlm. 174.

${ }^{12}$ Geertz misalnya memandang Islam, bahwa sebenarnya Islam tidak memilikipengaruh signifikan dalam budaya Jawa. Islam yang disebarkan di Jawa, dinilainya Islam yang sudah ditumpulkan dan dibelokkan ke dalam mistik India. Islam yang demikian terputus dari pusat ortodoksinya di Mekkah dan Kairo. Dengan demikian Islam di Jawa merupakan Islam sinkretis, yang sudah tercampur oleh budaya-budaya lokal yang bercorak Animisme, Budhisme-Hinduisme. Cliford Geertz, Abangan Santri Priyayi,( Jakarta: Dunia Pustaka Jaya, 1983), hlm.170.

13 Ciri utama gerakan Islam ini adalah menjadikan Islam sebagai ideologi politik. Islam dijadikan dalih dan senjata politik untuk mendiskreditkan dan menyerang siapapun yang dalam pandangan politik dan pemahaman keagamaannya berbeda dari mereka. Jargon memperjuangkan Islam sebenarnya adalah memperjuangkan agenda politik tertentu dengan menjadikan Islam sebagai kemasan dan senjatanya. Selain itu dengan dalih memperjuangkan Islam dan membelanya, mereka berusaha keras menolak budaya dan tradisi yang selama ini telah menjadi bagian integral kehidupan bangsa Indonesia, dengan menggantikannya dengan tradisi Timur Tengahlm. Dalam pandangan Gus Dur, ini terjadi 
yang ada dan berkembang di Arab, sehingga seluruh komunitas Islam harus mengikuti pola keberagamaan yang mereka anut dan mereka praktekkan. Tradisi dan adat Istiadat setempat bagi mereka merupakan bid'ah yang dapat mencemarkan ajaran Islam yang sesungguhnya. Namun bagi Abdurrahman Wahid14, Arabisasi atau proses mengidentifikasi diri dengan budaya Timur Tengah adalah akan tercerabutnya kita dari akar budaya kita sendiri. Lebih dari itu Arabisasi belum tentu cocok dengan kebutuhan kita. Menurutnya antara agama (Islam) dan budaya memiliki independensi masing-masing, tetapi keduanya memiliki wilayah yang tumpang tindih. Tumpang tindih agama dan budaya akan terjadi terus menerus sebagai suatu proses yang akan memperkaya kehidupan dan membuatnya tidak gersang. Dari sinilah sebenarnya gagasan tentang pribumisasi Islam menjadi sangat urgen. Karena dalam pribumisasi Islam tergambar bagaimana Islam sebagai ajaran normativ yang berasal dari Tuhan diakomodasikan kedalam kebudayaan yang berasal dari manusia tanpa kehilangan identitasnya masing-masing.

Pribumisasi bukan upaya menghindarkan timbulnya perlawanan dari kekuatan-kekuatan setempat, akan tetapi justru agar budaya itu tidak hilang. Karena itu inti pribumisasi Islam adalah kebutuhan bukan untuk menghindarkan polarisasi antara agama dan budaya, Sebab polarisasi demikian tidak terhindarkan. Pribumisasi Islam, dengan demikian menjadikan agama dan budaya tidak saling mengalahkan melainkan berwujud dalam pola nalar keagamaan yang tidak lagi mengambil bentuk yang autentik dari agama, serta berusaha mempertemukan jembatan yang selama ini memisahkan antara agama dan budaya. Dalam prakteknya, konsep pribumisasi Islam ini dalam semua bentuknya dimaksudkan untuk memberikan peluang bagi keanekaragaman interpretasi dalam praktek kehidupan beragama di setiap wilayah yang berbeda-beda.

Bila ditelusur lebih jauh, pribumisasi Islam di Indonesia merupakan keniscayaan sejarah. Sejak awal perkembangannya, Islam Indonesia khususnya di Jawa adalah Islam pribumi yang disebarkan oleh Walisongo dan pengikutnya dengan melakukan transformasi kultural dalam masyarakat. Islam dan tradisi tidak ditempatkan dalam posisi yang berhadap-hadapan, tetapi didudukkan dalam kerangka dialog kreatif,

karenamereka tidak mampu membedakan dari kultur tempat Islam di wahyukan. Abdurrahman Wahid, , "Musuh Dalam Selimut" sebuah pengantar pada buku Ilusi Negara Islam: Ekspansi Gerakan Islam Trans Nasional di Indonesia,( Jakarta: The Wahid Institute bekerjasama dengan Gerakan Bhinneka Tunggal Ika danMa'arif Institute, 2009), hlm. 19-20.

14 Abdurrahman Wahid, Pergulatan Negara, Agama, dan Kebudayaan,( Jakarta: Desantara, 2001), hlm.20 
dimana diharapkan terjadi transformasi didalamnya. Proses transformasi cultural tersebut pada gilirannya menghasilkan perpaduan antara dua entitas yaitu Islam dan budaya lokal. Perpaduan inilah yang melahirkan tradisi-tradisi Islami yang hingga saat ini masih dipraktekkan dalam berbagai komunitas islam kultural yang ada di Indonesia.

Dengan demikian dapat dipahami antara agama (Islam) dan budaya (lokal) masing-masing memiliki simbol-simbol dan nilai tersendiri.Agama (Islam) adalah simbol yang melambangkan ketaatan kepada Allah. Kebudayaan (lokal) juga mengandung nilai dan simbol supaya manusia bisa hidup didalamnya dengan cirri khas kelokalannya. Agma memerlukan sistem symbol dengan kata lain agama memerlukan kebudayaan agama. Tetapi keduanya perlu dibedakan . Agama adalah sesuatu yang final, universal, abadi (perenial), dan tidak mengenal perubahan perubahan (absolut) sedangkan kebudayaan bersifat particular, relative dan temporer. Agama tanpa kebudayaan memang dapat berkembang secara pribadi, tetapi tanpa kebudayaan agama sebagai kolektifitas tidak akan mendapatkan tempat.

Dengan demikian dialektika antara Islam dan kebudayaan lokal merupakan sebuah keniscayaan. Islam memberikan warna dan spirit pada budaya lokal di Jawa, sedangkan kebudayaan lokal memberi kekayaan terhadap agama Islam. Hal inilah yang terjadi dalam dinamika keIslaman yang terjadi di Indonesia khususnya di Jawa dengan tradisi dan kekayaan budayanya.

\section{Akulturasi dan Asimilasi: Kerangka konsep}

Akulturasi merupakan culture contact yang memiliki proses dua arah (two way process), saling mempengaruhi antara dua kelompok yang mengadakan hubungan, atau oleh Ortiz disebut transculturation untuk menunjuk suatu hubungan timbal balik (reciprocal) antar aspek kebudayaan ${ }^{15}$. Hubungan saling mempengaruhi antara kedua kebudayaan tersebut mengakibatkan terjadinya perubahan kebudayaan. Menurut Redfiel, Linton dan Herskovits ${ }^{16}$ akulturasi meliputi fenomena yang dihasilkan sejak dua kelompok yang berbeda kebudayaannya mulai melakukan kontak langsung, yang diikuti pola kebudayaan asli salah satu

\footnotetext{
${ }^{15}$ Hari Poerwanto, Kebudayaan dan Lingkungan dalam Perspektif Antropologi, (Yogyakarta: Pustaka Pelajar, 2000), hlm. 107.

16 Redfiel, Linton, dan Herskovits dalam Robert.HLM.Lauer, 1993, Perspektif Tentang Perubahan Sosial, Jakarta: Rienika Cipta. hlm. 403.
} 
atau kedua kelompok tersebut. Sedangkan menurut William A. Hafiland ${ }^{17}$ akulturasi adalah perubahan-perubahan besar dalam kebudayaan yang terjadi sebagai akibat dari kontak antar kebudayaan yang berlangsung lama.

Konsep akulturasi menurut Kuntjaraningrat ${ }^{18}$ adalah suatu bentuk proses sosial yang timbul bila suatu kelompok manusia dengan suatu kebudayaan tertentu dihadapkan dengan unsur-unsur kebudayaan asing (terjadi kontak budaya), yang mana unsur-unsur budaya asing lambat laun diterima dan diolah kedalam kebudayaan sendiri tanpa menghilangkan unsur-unsur kepribadian kebudayaan sendiri. Proses akulturasi ini sangat penting khususnya didaerah yang penduduknya plural (terdiri dari beragam suku, ras, agama, dan lain-lainnya) agar tercipta kehidupan yang harmonis. Di Indonesia pada umumnya lebih khusus pada Jawa proses akulturasi ini berlangsung cukup baik, misalnya akulturasi budaya Islam dengan budaya lokal, budaya pra Islam dengan budaya Islam, budaya modern dengan budaya tradisional, masing-masing diterima dan mengalami akulturasi satu sama lain tanpa harus kehilangan identitasnya sendiri.

Dari dua proses interaksi atau komunikasi ini, akan menghasilkan percampuran antara budaya yang berinteraksi yang selanjutnya dijadikan sebagai kebudayaan kolektif yang dipakai bersama. Dalam pengertian ini muncul istilah asimilasi budaya. Asimilasi adalah perpaduan dua atau lebih kebudayaan, kemudian menjadi satu kebudayaan baru tanpa adanya unsur-unsur paksaan. ${ }^{19}$ Proses ini bisa terjadi ketika ada dua kelompok atau lebih masyarakat dengan kebudayaan yang berbeda saling berinteraksi atas dasar sikap terbuka, sikap toleran, dari masing-masing kelompok. Biasanya asimilasi terjadi secara perlahan dan sangat evolutif dalam waktu yang relatif panjang, hingga tanpa terasa mereka mempunyai kebudayaan baru hasil dari campuran diantara yang berinteraksi.

17 Menurutnya akulturasi terjadi bila kelompok-kelompok individu yang memiliki kebudayaan yang saling berhubungan secara langsung dengan intensif, kemudian timbul perubahan-perubahan besar pada pola kebudayaan dari salah satu atau kedua kebudayaan yang bersangkutan. Diantara variable-variabelnya adalah tingkat perbedaan kebudayaan, keadaan, intensitas, frekwensi dan semangat persaudaraan dalam hubungannya, siapa yang dominan, dan siapa yang tunduk, dan apakah datangnya pengaruh itu timbale balik atau tidak. Baca William A. Haviland ,1985, Antropologi, Jakarta Erlangga, Jilid 2, hlm. 263.

18 Koentjaraningrat, Masalah Kebudayaan dan Integrasi Nasional", (Jakarta: UI Press, 1993). hlm. 248.

19 Mudzirin Yusuf, dkk, dalam Khadziq, tt, Islam dan Budaya Lokal, Yogyakarta:Teras, hlm.89. 
Kebudayaan sebagai hasil interaksi selanjutnya menjadi kesepakatan bersama dalam sebuah ikatan masyarakat.

Interaksi budaya baik akulturasi maupun asimilasi dapat terjadi dalam lingkup antar individu maupun antar kelompok. Dalam lingkup individu, proses interaksi dalam bentuk komunikasi akan membentuk kesepakatan bersama yang selanjutnya dipakai bersama, bahkan menjadi pengikat antar sesama mereka. Jika masing-masing buah pikiran merupakan budaya, maka hasil komunikasi tersebut adalah menjadi budaya bersama, atau yang disebut dengan budaya kolektif. Proses itu bisa terjadi dalam satu wilayah tertentu, sehingga terbentuk apa yang disebut dengan budaya lokal.

Para antropolog mencatat beberapa hal yang akan terjadi dalam akulturasi:20 1) Substitusi, unsur atau kompleks unsur-unsur kebudayaan yang ada sebelumnya diganti oleh yang memenuhi fungsinya dengan perubahan struktural yang tidak berarti; 2) Sinkretisme, unsur-unsur lama bercampur dengan yang baru dan membentuk sebuah sistem baru, dengan perubahan kebudayaan yang berarti; 3) Adisi (addition), unsur atau kompleks unsur baru ditambahkan pada yang lama, dengan perubahan atau tidak adanya perubahan struktural; 4) Dekulturasi, hilangnya bagian substansial dari sebuah kebudayaan; 5) Orijinasi (orgination), unsur-unsur baru yang memenuhi kebutuhan baru yang timbul karena perubahan situasi; 6) Penolakan (rejection), perubahan mungkin terjadi secara cepat, sehingga sejumlah orang mungkin tidak dapat menerimanya. Sehingga mengakibatkan timbulnya penolakan, pemberontakan atau gerakan kebangkitan.

\section{E. Proses Akulturasi Islam dan Budaya Jawa dalam Tradisi Nyumpet di Desa Sekuro}

Desa Sekuro merupakan salah satu desa yang terletak di Kecamatan Mlonggo, Kabupaten Jepara. Kecamatan Mlonggo terletak disebelah utara ibu kota Kabupaten Jepara, dengan batas - batas: Sebelah timur dengan Kec. Bangsri, sebelah barat dengan Laut Jawa, sebelah utara dengan Kecamatan Bangsri, sebelah selatan dengan Kecamatan Pakisaji. Secara administrasi kecamatan ini membawahi beberapa desa diantaranya; desa

20 Haviland, William A dan R.G.Soekadijo, 1985, Antropologi Jilid 2, (Jakarta: Erlangga). 
Jambu barat, desa Jambu Timur, desa Karanggondang, desa Mororejo, desa Sekuro, desa Sinanggul, desa Srobyong dan desa Suwawal.

Tempat studi ini dilakukan terletak diujung paling timur kecamatan Mlonggo berbatasan dengan kecamatan Bangsri. Setengah jam perjalanan dari Jepara sebagai Ibu Kota Kabupaten, Sekuro menandai titik dimana daerah bagian luar wilayah yang datar dan subur terletak disepanjang jalan Jepara-Bangsri dan Pati, dilengkapi dengan sentra kerajinan furniture sebagai salah satu tumpuan kehidupan masyarakatnya. Sebagai salah satu pusat industri furniture, Sekuro dihuni sekitar 600 kepala keluarga dengan mata pencaharian $70 \%$ sebagai pengrajin atau tukang kayu dan selebihnya berprofesi sebagai petani, buruh tani, PNS, dan pedagang. Dalam kesehariannya peran mereka didukung oleh fasilitas umum yang memadai, bentuknya setiap aktifitas warga mendapat akses transportasi. Setiap jalan telah beraspal halus dengan berbagai transportasi yang melengkapi aktifitas masyarakat seperti bis dengan rute Jepara-Bangsri-Pati dan angkutan desa untuk akses pedalamannya.

Pada sisi lain desa ini dikelilingi oleh sawah kecil dan dibagian selatan desa dikelilingi sungai yang mengalirkan airnya menuju laut Jawa, dengan mengandalkan sistem tadah hujan dan sebuah sistem irigasi klasik berupa selokan sebagai cara untuk mengalirkan air keberbagai sawah, yang ada di tepi perkampungan. Pada musim kemarau sebagaimana ditempat lain, sawah disini tidak dibiarkan menganggur tetapi ditanami palawija, biasanya ditanami ketela pohon, ketela rambat, jagung, kacang, dan kedelai.

Bagi masyarakat yang memiliki keahlian sebagai tukang kayu, mereka biasanya membuka usaha sendiri atau bekerja pada juragan mebel, atau pergi merantau ke Jakarta atau tempat-tempat lain yang menyediakan lapangan kerja dibidang furniture. Profesi ini biasanya ditekuni para angkatan muda, mereka lebih senang bekerja pada industri kayu daripada sebagai petani yang cenderung dilakukan oleh angkatan tua. Ketika krisis ekonomi tahun 1997 masyarakat Sekuro memiliki penghidupan yang sangat mapan karena nilai tukar rupiah dan aktifitas ekonomi di Jepara pada umumnya menggunakan standar dollar, dimana masa itu nilai dollar sedang naik dan banyak dari masyarakat Sekuro yang menjadi juragan mebel. Hampir setiap rumah memiliki bedeng (gudang) untuk mengerjakan pesanan dan menyimpan barang-barang hasil kerajinan untuk diekspor. Sehingga berbagai persaingan materi mewarnai kehidupan masyarakatnya, baik persaingan dalam membangun rumah, membeli mobil, perkakas rumah tangga, dan bahkan pesaingan dalam menambah jumlah istri.

Tetapi ketika nilai tukar dollar stabil dan bahan baku (kayu jati) mengalami kepunahan, para juragan mebel mengalami kerugian dan 
mereka akhirnya kembali kepada pekerjaan semula sebagai tukang kayu biasa, dengan upah yang jauh berbeda ketika masa-masa kejayaan menghampirinya. Upah yang didapatkan para pekerja tersebut, pada bulanbulan tertentu bisa dikatakan tidak mampu untuk memenuhi keperluan sehari-hari karena munculnya kebutuhan dan tanggung jawab sosial yang dianggap lebih penting daripada kebutuhannya sendiri yaitu adatkebiasaan menyumbang. Pada bulan-bulan tersebut, dalam pribahasa yang popular disebut "besar pasak daripada tiang" sangat dirasakan masyarakat pada umumnya. Masa-masa sulit ini dirasakan oleh semua lapisan masyarakat ketika musim hajatan baik khitanan (sunatan) dan perkawinan.

Upacara untuk merayakan khitanan pada umumnya menyerupai pola upacara perkawinan, tentu saja dengan meniadakan persandingan antara pengantin pria dan wanita. Dengan demikian hidangan dan tata cara upacara khitanan atau sunatan sama dengan hidangan perkawinan. Kedua upacara itu memberi kesempatan pengeluaran yang sangat besar dan berlebihan dalam tradisi di Sekuro dan masyarakat jawa pada umumnya.

Biasanya hajatan digelar pada bulan Besar, Maulud, Rajab, Ruwah, Syawal. Pada bulan-bulan ini biasanya setiap hari ada orang yang menggelar hajatan, bahkan terkadang satu hari masyarakat setempat harus menghadiri dua hingga tiga pesta hajatan. Ada sejumlah dua ratus undangan bahkan ada yang lebih, untuk dijamu dalam pesta yang mengiringi selamatannya dan mereka diharapkan membawa oleh-oleh , hadiah, atau dalam bentuk uang. Bila di daerah lain (diluar jepara) menghadiri pesta dengan menyumbang berupa uang dalam satu amplop untuk mewakili keluarganya, di daerah ini lebih ditekankan pada sumbangan barang (lebih bernilai dibanding uang) dan tiap-tiap anggota keluarga yang mengenal sang empunya hajat, maka harus ikut menyumbang. Para ibu datang ke pesta dengan membawa buah tangan berupa gula sedangkan bapak-bapak membawa rokok satu press (slop) atau lebih disesuaikan dengan ikatan keluarga dan pertemanan, sedangkan jika memiliki anak yang kenal dengan sang pengantin atau anak yang di sunat maka sang anak sebagaimana adat yang berlaku juga membawa barang sumbangan untuk dipersembahkan pada pengantin atau anak yang disunat.

Untuk menyambut datangnya sang tamu, pemilik hajat mempersiapkan berbagai upacara seminggu menjelang pelaksanaan hajatan dengan harapan mendapat perlindungan dari Sang pencipta dan para nenek moyang yang telah mendahului di alam baka. Sebagaimana yang dilaksanakan keluarga Bapak Safuan, Keluarga ini akan mengadakan 
hajatan sunatan sekaligus mantenan putri sulungnya pada tanggal 5 Pebruari 2013, namun seminggu sebelum perayaan pesta itu, keluarga dan tetangga sudah mulai terlibat dalam persiapan tradisi upacara pernikahan.

Penulis akan menguraikan adat-kebiasaan yang dilakukan seminggu menjelang pesta pernikahan yang dianggap paling signifikan untuk dilaksanakan adalah tradisi "nyumpet". Nyumpet dilaksanakan dengan harapan akan terjadi keselamatan dalam pelaksanaan pesta yang dimulai sebelum pesta, pelaksanaan pesta dan setelah pesta.

Nyumpet dalam bahasa Jawa memiliki arti melindungi, menutupi , merapeti atau memagari. Secara istilah nyumpet memiliki arti mbuntoni atau ngrapeti lubang atau jalan dari berbagai gangguan baik secara kasat mata (dalam bentuk dhohir) maupun yang tidak terindera secara fisik agar dalam melaksanakan hajatan tercapai dengan selamet. Nyumpet atau permohonan keselamatan ini dilakukan menjelang pelaksanaan prosesi pernikahan (7 hari sebelum pernikahan digelar) dengan harapan selamat dari tolak balak, dibebaskan dari gangguan makhluk metafisik seperti memedi, lelembut, setan gundul, demit, siluman, serta sifat manusia seperti lowo kalong, atau sukmo nglemboro seperti kucing, babi ngepet, kilah agar jrangkong, wewe,wujung-wujung (pocong) yang mengganggu keberhasilan prosesi pernikahan.

Memedi adalah istilah Jawa untuk jenis roh yang menakut-nakuti, paling mudah dipahami atau disebut juga hantu. Memedi ini biasanya disamakan dengan jrangkong yaitu kerangka manusia yang hadir "tanpa daging" atau disamakan juga dengan wedon yaitu makhluk halus dalam bungkus kain putih atau dikenal dengan pocong. Makhluk ini bisa terlihat meski dalam keadaan gelap tanpa lampu yang siap mengganggu manusia apalagi ketika pesta pernikahan akan digelar. Lelembut yaitu roh yang menyebabkan kesurupan. Terkadang orang menyebutnya dengan genderuwo, setan, demit, atau jin yaitu jenis roh yang masuk kedalam diri seseorang yang akan mengakibatkan kesurupan. Merupakan permasalahan yang cukup serius karena petemuan dengan mereka akan berakhir dengan sakit, gila, atau kematian. Tuyul yaitu makhluk halus yang akrab dengan manusia. Ia mampu mencuri uang untuk tuannya dan tidak mudah untuk dilacak. Demit yaitu makhluk halus yang menghuni suatu tempat biasanya berada di tempat-tempat keramat yang disebut punden, yang ditandai dengan pepohonan yang besar seperti beringin, kuburan tua, sumber air yang letaknya tersembunyi, reruntuhan candi dan kekhususan semacam itu.

Lowo, kalong, serta sukmo nglemboro seperti kucing babi ngepet memiliki dua pengertian pertama, sifat manusia yang suka mengambil hak 
orang lain dengan cara-cara yang culas. Yang kedua berupa siluman (bentuk dari pesugihan seseorang berupa kalong, lowo, dan lain-lain) yang bertugas mengambil harta dari hasil orang yang memiliki hajat.

Selain untuk melindungi hajat dari serangan makhluk halus, nyumpet digunakan pula untuk mendapatkan hasil (materi) berlebih untuk mengumplkan rejeki, atau bagi orang yang sudah kaya semata-mata bukan hasilnya tetapi kehadiran banyak tamu sangat menunjukkan prestis yang memiliki hajat.

Untuk melaksanakan prosesi ini, dibutuhkan seseorang yang mampu melaksanakan tugas upacara ini. Pak Safuan sang pemilik hajat, datang pada orang "pintar" yang bisa menjalankan ritualnya yang ada di desa Sekuro, kemudian memintanya untuk melaksanakan tugasnya yaitu nyumpet. Sang penyumpet kemudian meminta untuk disediakan uga rampe (peralatan atau syarat-syarat yang harus dipenuhi dan harus disediakan oleh tuan rumah).

Uga rampe yang harus disediakan meliputi:

1. Paso kekep berisi beras sepenuhnya paso, sehingga membentuk gunung dengan satu telur ayam kampung diujung di tengah paso. wadah harus kekep, diibaratkan sebuah bumi. Beras merupakan simbol fitrah manusia, dalam kiprahnya ikut membantu terlaksananya hajat. Telur simbul hajat yang disengkuyung atau diangkat bersama-sama sehingga hajatnya dapat mendatangkan banyak rizki.

2. Jadah pasar terdiri dari berbagai jajanan yang ada di pasar dan bahan bakunya berasal dari beras. Mensimbolkan sifat yang bermacammacam dari beras (manusia) dengan wadah atau tempatnya tebok.

3. Sifat itu terdiri dari bermacam-macam sebagaimana isinya yang ada dalam tebok atau jagad itu. Tebok merupakan manifestasi dari jagad atau alam semesta yang memiliki sifat- sifat yang beragam.

4. Bubur abang 4, putih 4, segelas kopi hitam dan segelas susu putih, arang-arang kambang, rujak degan atau kelapa muda yang diberi gula jawa. Bubur simbol dari khormat (menghormati) kakang kawah adi ariari (menghormati asal muasal kejadian manusia yang berasal dari darah merah dan putih), 4,5 (empat,lima) pancer. 4 (empat) $=$ (sama dengan) 4 (empat) penjuru wetan (timur), kulon (barat), kidul (selatan), elor (utara). Sedangkan 5 (lima) = (sama dengan) orang yang memiliki hajat berbentuk badan yang punya hajat.

5. Dinampan yang berbeda, terdapat sajian susu dan kopi perwujudan dari alam, keselametan siang dan malam. 
6. Bunga telon warna merah hijau putih, lambang dari pertolongan dari Yang Kuasa. Telon artinya pertolongan. Jadi simbol bunga telon sebagai pengantar untuk mendapatkan pertolongan Sang Kuasa.

7. Rujak degan yaitu agar permohonan menjadi mantap jangan ragu-ragu, harus madep mantep pada sang Hyangwidi.

8. Arang-arang kambang dibuat dari beras ketan digoreng dengan gula, sesudah menguning atau menghitam dikepel atau dikumpul-kan hingga melekat antara satu dengan lainnya, kemudian diberi air dimasukkan dalam gelas simbol agar madep mantep atine pada pengeran jangan was-was atau kemambang pada pangeran yang memberikan apa yang diinginkan hambanya.

9. Kupat lepet simbol semua yang dihajatkan memiliki kesalahan semoga sang Hyangwidi memberikan maaf.

10. Carang pring (ranting bambu yang kering satu meter panjangnya) dengan lawe (tali dari benang) putih satu helai. Fungsi permohonan cuaca terang terbebas dari gangguan hujan (singkir air).

11. Garam krosok (garam yang belum dimasak oleh pabrik) yaitu untuk membentengi rumah agar terhindar dari makhluk metafisik.

12. Dupa atau menyan jawa yaitu alat untuk mengantarkan doa atau hajat

13. Satu kamar khusus yang tdk boleh dimasuki selain yang punya hajat.

14. Lampu senthir atau teplok yaitu lampu minyak berukuran kecil dan harus hidup selama seminggu dalam kamar yang menjadi tempat nyumpet. Jika tidak ada lampu senthir, bisa digantikan lilin.

15. Jangka waktu satu minggu sebelum hajat permintaan dipanjatkan dengan ritual do'a.

Sedangkan runtutan Nyumpet dapat diuraikan sebagai berikut:

1. Prosesi nyumpet diawali dengan do'a yang dikemas dalam acara slametan 


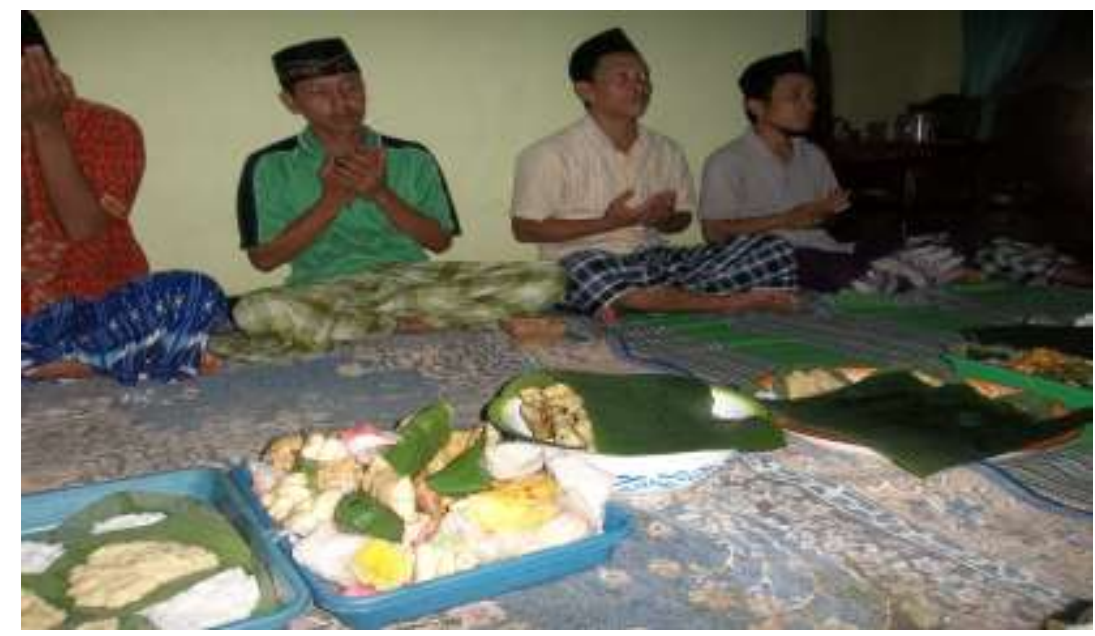

Gambar 1: Slametan nyumpet dan ngrasulake (Dok.Penulis)

Slamatan nyumpet merupakan perwujudan minta ijin atau permisi pada danyang, agar disengkuyung (dibantu) dalam melaksanakan hajatnya, dan diijabah gusti apa yang menjadi permohonannya. Danyang (roh pelindung) adalah roh tokoh-tokoh sejarah yang sudah meninggal sebagai pendiri desa tempat mereka tinggal. Danyang ini sebagai orang pertama yang membuka tanah sekuro. Setiap desa memiliki danyang utama. Danyang desa ini adalah Mbah Kawak. Ketika Mbah Kawak masih hidup sebagai manusia, datang ke desa itu selagi masih hutan belantara, jadi dia yang membuka tanah sekuro pertama kali dengan cara membersihkannya, dan membagi-bagikan tanah pada pengikutnya, keluarganya, teman-temannya, dan ia sendiri sebagai lurahnya. Sesudah meninggal kemudian dia dimakamkan didekat desa tempat mereka tinggal yaitu d idesa Kawak sebelah selatan desa Sekuro. Dalam kepercayaan masyarakat setempat, ia sendiri masih terus memperhatikan kesejahteraan desanya meski berbeda alamnya. Mbah Kawak sendiri sudah masuk Islam ketika membabad tanah sekuro. Hal ini ditandai dengan berdirinya masjid Kawak yang didirikan, dan dibuat bersama masyarakat setempat. Peninggalan masjid tersebut hingga sekarang masih terawat dengan baik serta dilestarikan masyarakat Kawak. Namu secara umum dan yang belum tentu beragama Islam, tetapi bisa saja memiliki kepercayaan pada agama tradisional, Hindhu maupun Budha, tetapi dia memiliki peran 
utama dalam pendirian sutu desa yaitu sebagai orang yang membuka wilayah yang pertama kali.

2. Doa untuk Danyang dibacakan ketika "Nyumpet dan Ngrasulake". Dilakukan seminggu sebelumnya dibarengi ngrasulake. Ngrasulake yaitu kirim do'a untuk para rasul, para nabi , sahabat, tabiin sampai pada leluhurnya dengan disertai sajian seperti nyumpet ditambah ingkung ayam. Dalam waktu bersamaan dengan nyumpetnya dan dihadiri para tetangga yang diundang untuk ikut mendoakan.

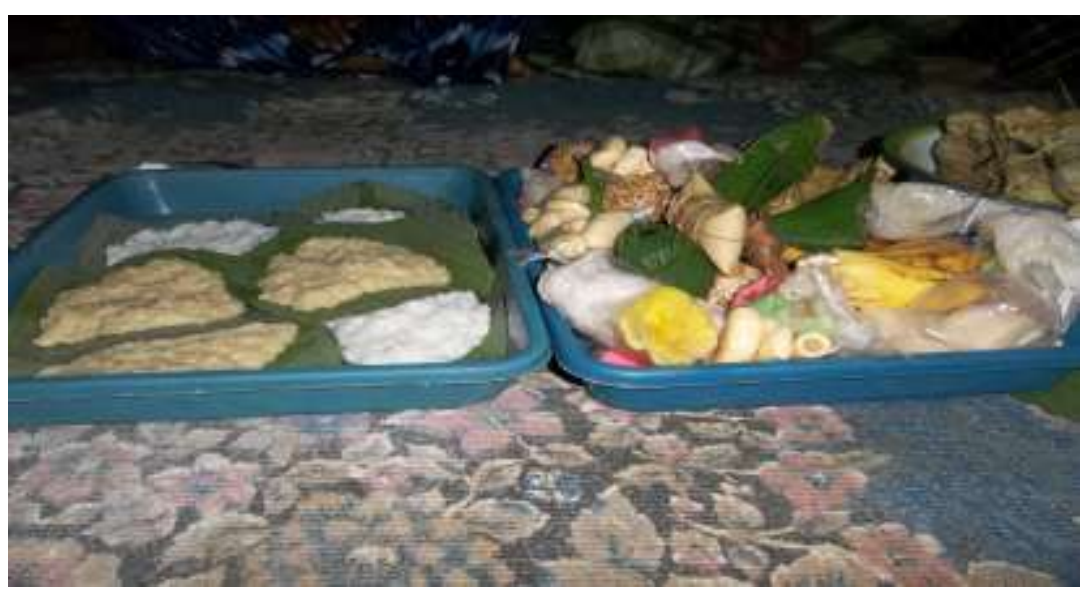

Gambar 2: Ugorampe ngrasulake (Dok.Penulis)

3. Nyumpet dilakukan oleh tokoh spiritual yang ada di desa ini sebut saja Pak Heri. Pak Heri merupakan tokoh spiritual yang umurnya masih sangat muda sekitar 30tahun, namun karena daya linuwihnya (memiliki kelebihan dibidang spiritual dan magis) ia diberi kepercayaan untuk melakukan ritual upacara itu dan memimpin doa doanya. Menurutnya, nyumpet dibutuhkan tempat khusus untuk membacakan do'a-do'a beserta ugorampe di kamar yang disediakan dan tidak boleh ada orang lain yang memasukinya hingga pesta selesai kecuali sang punya hajat.

4. Selanjutnya paso ditutup setelah diberi do'a, kemudian dibuka lagi menjelang sehari sebelum pesta dimulai yaitu pada malam melek pasian . Kekep dibuka dari pasonya dengan maksud membuka do'a-do'a yang sudah dipanjatkan. Seperti permintaan rezeki dilimpahkan, tidak ada gangguan apapun serta cuaca pada saat berlangsungnya pesta 
menjadi cerah, meskipun ada hujan tetapi hujan tersebut tidak berlangsung lama sehingga tanah menjadi kering lagi tidak ada air yang akan mengganggu aktifitas hajat. Bersamaan waktu membuka paso, carang dan lawe yang diikatkan pada carangnya diambil dari kamar kemudian ditancapkan dibelakang rumah ditempat lapang tanpa ada halangan. Gunanya untuk menyingkirkan atau khusus menolak datangnya hujan .

5. Kirim nduwo atau kirim do'a pada ahli kubur shohibul hajat pada melek pasian (melek semaleman di malam hari sebelum pelaksanaan pesta esok harinya). Melek pasian ini dilakukan oleh saudara, tetangga, dan teman dekat untuk mengantarkan dan menghormati sang mempelai dalam mengarungi rumah tangga.

Setelah pesta selesai maka ritual ditutup dengan selamatan sepasar dengan ugorampe jajan pasar, bubur merah putih, ingkung, nasi golong. Undangan tetangga terdekat, tujuannya untuk bersyukur atas keberhasilan hajatnya, dan selamatan penutup hajat.

\section{F. Simpulan}

Dari hasil pembahasan tentang pergumulan Islam dan budaya lokal, baik secara teoritik dan praktik (dengan studi kasus yang dipilih), penulis dapat mengambil beberapa catatan sebagai berikut: Pertama, Islam sebagai agama paripurna memiliki nilai-nilai ideal yang seharusnya menjadi pedoman perilaku bagi setiap orang yang memeluknya. Cepat-lambatnya internalisasi tersebut sangat dipengaruhi oleh berbagai macam hal diantarannya adalah konteks sosio-kulturalnya. Kedua, akulturasi merupakan konsep untuk menggambarkan proses panjang bertemunya dua atau lebih tata nilai antara Islam dengan nilai-nilai lokal dimana individu, kelompok dan masyarakat bertempat tinggal dengan budaya yang telah dimilikinya. Apa yang akan terjadi dalam proses ini seperti substitusi, sinkretisme, adisi, dekulturasi, orijinasi dan bahkan penolakan, harus dipahami sebagai bagian kecintaan mereka terhadap nilai-nilai lama (lokal) pada satu sisi dan proses belajar untuk memahami nilai-nilai baru (Islam) pada sisi yang lain. Pada kondisi seperti ini ini, tidak tepat digunakan klaim menang atau kalah, antara Islam vis a vis budaya lokal. Ketiga, pemahaman masyarakat tentang ajaran Islam sebagaimana telah dipaparkan sebelumnya, dengan kelebihan dan kekurangannya merupakan wujud dimulainya era keterbukaan msyarakat tersebut terhadap budaya-budaya dari luar termasuk di dalamnya nilai-nilai ajaran Islam. Diperlukan bimbingan dan pendampingan untuk mencapai tahapan pemahaman dan tahapan implementasi ajaran Islam yang lebih sempurna. 


\section{DAFTAR PUSTAKA}

Anasom (ed), Merumuskan kembali Interelasi Islam-Jawa, (Yogyakarta: Gama Media bekerjasama dengan Pusat Kajian Islam dan Budaya Jawa IAIN Walisongo Semarang, 2004).

Asy'ari, Musa, Manusia pembentuk kebudayaan dalam al-Qur'an, (Yogyakarta: LESFI, 1992).

Bruinessen, Martin Van, 1996, "Global and Local in Indonesia Islam" dalam Southeast Asian Studies, Kyoto: vol 37, No 2. 1996

Cassirer, E. An Essay on Man, An Introduction to Philosophy of Human Culture, (New Heaven: New York, 1994)

Geertz, Cliford, Abangan Santri Priyayi, (Jakarta: Dunia Pustaka Jaya, 1983).

Hartini , Kartasapoetra, Kamus Sosiologi dan Kependudukan, (Jakarta: BumiAksara, 1992).

Haviland, William A., Antropologi Jilid 1, (Jakarta: Erlangga, 1985). Antropologi Jilid 2, (Jakarta: Erlangga, 1985).

ISTIQRO', 2007, Jurnal penelitian Islam Indonesia, Volume 06, No. 1 Tahun 2007.

Khadziq, tt, Islam dan Budaya Lokal, (Yogyakarta: Teras, tt).

Koentjaraningrat, Masalah Kebudayaan dan Integrasi Nasional, (Jakarta: UI Press, 1993).

, Kebudayaan, Mentalitet, dan Pembangunan, Jakarta: Gramedia, 1974).

Lauer, Robert.H, Perspektif Tentang Perubahan Sosial, (Jakarta: Rienika Cipta, 1993).

Lombard, Denys, Nusa Jawa Silang Budaya, (Jakarta: Gramedia, 1996).

Nothingham, Elizabeth K., Agama dan Masyarakat, (Jakarta: Rajawali Press, 1997).

Poerwanto,Hari, Kebudayaan dan Lingkungan dalam Perspektif Antropologi (Yogyakarta: Pustaka Pelajar, 2000).

Syam, Nur, Madzhab-madzab Antropologi, (Yogyakarta: LKIS, 2007). 
Wahid, Abdurrahman, Ilusi Negara Islam: Ekspansi Gerakan Islam Trans Nasional di Indonesia, (Jakarta: The Wahid Institute, 2009).

--------------------, Pergulatan Negara, Agama, dan Kebudayaan, (Jakarta: Desantara, 2001).

www. isjd.pdii.lipi.go.id/admin/jurnal/61085766_0216-0188.pdf 